\title{
Hydrological evidence for a North Atlantic oscillation during the Little Ice Age outside its range observed since 1850
}

\section{Martín-Puertas ${ }^{1}$, I. Dorado-Liñán ${ }^{1}$, A. Brauer ${ }^{1}$, E. Zorita ${ }^{2,3}$, B. L. Valero-Garcés ${ }^{4}$, and E. Gutierrez ${ }^{5}$}

${ }^{1}$ Helmholtz-Zentrum Potsdam, Deutsches GeoForschungZentrum, Sektion 5.2 Klimadynamik und Landschaftsentwicklung, Telegrafenberg, 14473 Potsdam, Germany

${ }^{2}$ Helmholtz-Zentrum Geesthacht, Geesthacht, Germany

${ }^{3}$ Bert Bolin Centre for climate Research, University of Stockholm, Sweden.

${ }^{4}$ Instituto Pirenaico de Ecología CSIC. Apdo 13034, 50080, Zaragoza, Spain

${ }^{5}$ Universitat de Barcelona. Departament d'Ecologia. Diagonal 643, 08028, Barcelona, Spain

Received: 15 November 2011 - Accepted: 19 November 2011 - Published: 2 December 2011

Correspondence to: C. Martín-Puertas (celia@gfz-potsdam.de)

Published by Copernicus Publications on behalf of the European Geosciences Union.
7, 4149-4171, 2011

Evidence for a North Atlantic Oscillation

outside its observed range

C. Martín-Puertas et al.

\section{Title Page}

\section{Abstract}

Introduction

Conclusions

References

Tables

Figures

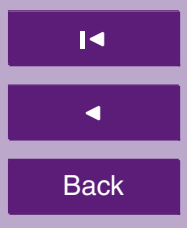

$>1$

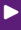

Close

\section{Full Screen / Esc}

Printer-friendly Version

Interactive Discussion 


\section{Abstract}

An annual-resolved precipitation reconstruction for the last $800 \mathrm{yr}$ in Southern Spain has been performed using stable carbon isotope $\left(\delta^{13} \mathrm{C}\right)$ of Pinus nigra tree rings. The reconstruction exhibits high- to low-frequency variability and distinguishes a Little Ice

5 Age (LIA, AD 1350-1850) characterized by lower averaged rainfall than both in the transition from the Medieval Climate Anomaly to the LIA and in the 20th century. The driest conditions are recorded during the Maunder solar Minimum (mid 17th-early 18th centuries), in good agreement with the Spanish documentary archive. Similar linkage between solar activity (maximum/minimum) and precipitation (increase/decrease) is observed throughout the entire LIA. Additionally, the relationship between the hydrological pattern in the Iberian Peninsula and Morocco during the LIA suggests different spatial distribution of precipitation in the south-eastern sector of the North Atlantic region such as it is known currently. Whereas in the instrumental record the precipitation evolves similarly in both regions and opposite to the North Atlantic oscillation (NAO) 15 index, the coldest periods of the LIA shows a contrasting pattern with drier conditions in the South of Spain and wetter in Northern Africa. We suggest an extreme negative NAO conditions, accompanied by a southward excursion of the winter rainfall band beyond that observed in the last century, can explain this contrast. The sustained NAO conditions could have been triggered by solar minima and higher volcanic activity during the LIA.

\section{Introduction}

Multi-decadal natural climate variability during the last millennium in Europe showed cooling stages occurring within a climate period so-called the Little Ice Age (LIA, AD 1350-1850). The most studied episode is the Maunder Minimum (MM, mid 17th- early 18th centuries) characterized by a reduction of European annual mean temperature of 1 to $1.5^{\circ} \mathrm{C}$ (Pfister, 1995). This cooling is thought to be related to a weaker solar
$7,4149-4171,2011$

\section{Evidence for a North Atlantic Oscillation outside its observed range}

\section{Martín-Puertas et al.}

\section{Title Page}

Abstract Introduction

Conclusions References

Tables Figures

14 $\rightarrow 1$

4

\section{Back}

Close

Full Screen / Esc

Printer-friendly Version

Interactive Discussion 
output and increased volcanic activity (Wanner et al., 2008). General Circulation Models suggest that it was also reinforced in Western Europe by a shift towards the negative Arctic Oscillation/North Atlantic Oscillation (AO/NAO) induced by a weaker solar forcing (Shindell et al., 2001; Langematz et al., 2005). Short-term solar cycle (11$5 \mathrm{yr}$ ) via changes in the solar ultraviolet irradiance and the consequent changes in the stratospheric ozone concentration may influence on the NAO index (Kodera, 2002; Matthes et al., 2006, 2011; Ineson et al., 2011). Based on an ocean-tropospherestratosphere climate model, Ineson et al. (2011) suggest that the simulated response of the surface climate during the last $80 \mathrm{yr}$ of solar minima resembles the negative 10 NAO conditions in the Northern Hemisphere. The NAO, a natural pattern resembling a meridional sea-saw of atmospheric pressure between the Azores and Iceland, strongly modulates climate anomalies in Western Europe, Eastern North America, Arctic and Mediterranean regions on sub-decadal timescales (Hurrell, 1995). Changes in the NAO index are accompanied by a latitudinal displacement of the mid-latitude wester15 lies and associated storm tracks. It can be seen that within its range of variations, the maximum of precipitation anomalies shift by about 25 degrees latitude, from $62^{\circ} \mathrm{N}$ to $38^{\circ} \mathrm{N}$. North and south of the maximum-precipitation band, precipitation anomalies are negative (Fig. 1a). The most recent example occurred in the 2009/2010 winter coinciding with the minimum of solar cycle 23 . In that winter, the NAO index attained its most negative value $(-2.4)$ recorded on the instrumental series and was accompanied by a southerly displacement of the mid-latitude westerlies and associated storm tracks, by atmospheric blocking that lead to both cooling over the mid-latitude landmasses of the Northern Hemisphere including Europe and the USA (Seager et al., 2010) and by the highest precipitation of the last two centuries in the South of the Iberian Peninsula and 25 Northern Africa (Vicente-Serrano et al., 2011) (Fig. 1a top).

Comparison between continuous hydrological records at the northern (Scotland) and the southern (Morocco) nodes of the NAO dipole has allowed reconstructing the NAO index for the last millennium (Trouet et al., 2009). It describes predominance of negative values throughout the LIA. This index reconstruction based on hydrological proxies
$7,4149-4171,2011$

\section{Evidence for a North Atlantic Oscillation outside its observed range}

C. Martín-Puertas et al.

\section{Title Page}

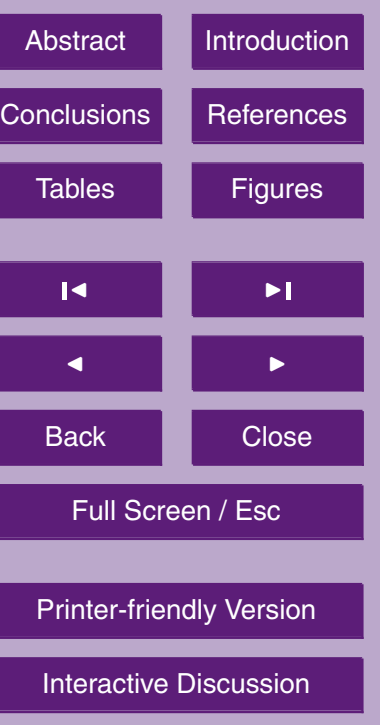

Interactive Discussion 
would be in good agreement with climate models that explain the temperature pattern for the MM (e.g., Shindell et al., 2001). However, additional proxies sensitive to precipitation in Southern Europe indicate a more complex picture during this period. Along the whole Iberian Peninsula $\left(40-36^{\circ} \mathrm{N}\right)$, an increased number of 'rogations' praying 5 for rain suggests a drought pattern in both Mediterranean and Atlantic regions during the second half of the 17th and the beginning of the 18th century coinciding with the MM (Barriendos, 1997; Vicente Serrano and Cuadrat, 2007; Rodrigo and Barriendos, 2008; Domingez-Castro et al., 2010, 2011). Unfortunately, the available proxy-data for the Iberian Peninsula do not allow a detailed study of the hydrological variability 10 covering the whole LIA. On the one hand, high-resolved proxies, such as documentary resources, do not cover the entire period and available tree-rings based precipitation reconstructions in Spain only display variability at high frequencies (Nicault et al., 2007); on the other hand, chronological models of the Iberian sedimentary records do not have sufficient resolution to depict the hydrological evolution on inter-annual to multi5 decadal timescale (Moreno et al., 2011; Morellón et al., 2011). On the other hand, the coincidence between the Iberian droughts and the Maunder minimum in solar activity could suggest a solar-climate linkage, which however cannot easily be explained in terms of physical mechanisms (i.e. variations of the NAO) (Domínguez-Castro et al., 2010), since a more negative NAO is accompanied in the present climate by higher precipitation in the Iberian Peninusla.

In this study we analyse, for the first time, precipitation reconstruction based on a tree-ring proxy for the last $800 \mathrm{yr}$ in Southern Spain, providing the longest annualresolved record for the Iberian Peninsula. The main goal is to describe the hydrological variability within the LIA in South-Western Europe on inter-annual to centennial timescales and to discuss the possible driving mechanisms and climate forcing behind these variations.
$7,4149-4171,2011$

\section{Evidence for a North Atlantic Oscillation outside its observed range}

C. Martín-Puertas et al.

\section{Title Page}

Abstract

Conclusions

Tables
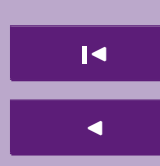

Back
Introduction

References

Figures

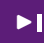

$\triangleright$

Close
Full Screen / Esc

Printer-friendly Version

Interactive Discussion 


\section{Regional setting}

The study site is a Pinus nigra subsp. salzmannii (Dunal) forest located at the Cazorla Range, in the Natural Park of Sierra de Cazorla, Segura y las Villas $\left(37^{\circ} 48^{\prime} \mathrm{N}, 2^{\circ} 57^{\prime} \mathrm{W}\right.$, $1800 \mathrm{~m}$ a.s.l.) (Fig. 1b,c). It is the oldest forest found up to now in the Iberian Peninsula 5 (Creus Novau, 1998). The reliable length of the tree-ring chronology covers almost the last millennium. This forest has a high paleoclimatic value since it is located in the altitudinal limit of the species distribution, where human influence is low.

The climate of Natural Park of Sierra de Cazorla, Segura y las Villas is Mediterranean characterized by cold and wet winters and very warm summers. Precipitation is exceptionally high ( $800 \mathrm{~mm}$ on average annual precipitation) in comparison with typical dry areas from the southeast of the Iberian Peninsula (Heywood, 1961). The seasonal precipitation distribution is: winter $(36.8 \%)$, spring $(27.6 \%)$, summer $(6.2 \%)$ and autumn (28.4\%) (Fig. 1d).

\section{Materials and methods}

\subsection{Tree-ring data and chronology development}

Sampling was carried out in Puertollano-Cabañas, Sierra de Cazorla Segura y las Villas $\left(37^{\circ} 48^{\prime} \mathrm{N}, 02^{\circ} 57^{\prime} \mathrm{W}, 1800 \mathrm{~m}\right.$ a.s.I.). 89 samples were taken in a Pinus nigra subsp. salzmannii (Dunal) forest from 40 dominant living trees with ages between 250 and $900 \mathrm{yr}$ old. According to standard procedures, cores were visual cross dated, tree ring widths measured (TRW) with an accuracy of $0.01 \mathrm{~mm}$ using the linear table Lintab ${ }^{\mathrm{TM}}$ (Frank Rinn S.A., Heidelberg, Germany) and the TSAP-Win program. The quality and correct dating of the resulting series were checked with COFECHA (Holmes, 1983). Four of the collected cores were selected for isotopic analysis. Tree rings were split manually with a scalpel under a stereomicroscope, and the $\alpha$-cellulose extracted chem- ically. The total length of the chronology is a combination of individual measurements
$7,4149-4171,2011$

\section{Evidence for a North Atlantic Oscillation outside its observed range \\ C. Martín-Puertas et al.}

\section{Title Page}

Abstract

Conclusions

Tables

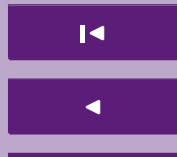

Back

\section{Introduction}

References

Figures

$\rightarrow 1$

Close

\section{Full Screen / Esc}

Printer-friendly Version

Interactive Discussion 
and a pool of the same trees (Fig. 2). The similarity of the results yield by these two methodological approaches was successfully tested in Dorado Liñán et al. (2011). The isotope ratios are given in the conventional delta $(\delta)$ notation, relative to the standards VPDB $\left(\delta^{13} \mathrm{C}\right)$ and VSMOW $\left(\delta^{18} \mathrm{O}\right)$. Signal strength of the master chronologies were 5 assessed using the Express Population Signal (EPS) to ensure reliability and representativeness of the final chronologies. For this study, a final chronology has been established based on stable carbon isotope $\left(\delta^{13} \mathrm{C}\right)$ of tree-rings.

\subsection{Precipitation reconstruction based on $\delta^{13} \mathrm{C}$}

Correlations between $\delta^{13} \mathrm{C}$ and monthly climate instrumental data from 1901-2006 10 CRU TS3.0 database (Mitchell and Jones, 2005) covering the geographical box 36$40^{\circ} \mathrm{N}, 4-0^{\circ} \mathrm{W}$, were calculated with monthly data and for different combinations of seasonal means. The calibration against the overlapping instrumental record was performed applying standard regression techniques. The statistical coefficients of determination and reduction of error (RE) were calculated (Table 1). Confidence intervals 5 were calculated in order to establish the uncertainty related to the calibration model used for reconstruction. $\delta^{13} \mathrm{C}$ shows a significant negative moisture signal (Fig. 3a). At the same time, a significant positive relationship with summer-to-early-autumn temperature occurs, but only the precipitation signal is temporally stable (Andreu-Hayles et al., 2011; Dorado Liñán, 2011). The negative correlation between $\delta^{13} \mathrm{C}$ and summer precipitation has been reported for different pine species across the Iberian Peninsula (Andreu et al., 2008; Voltas et al., 2008), the Alps (Treydte et al., 2001; Gagen et al., 2006) and in Finish Lapland (Gagen et al., 2007). Indeed, this common summer precipitation signal seems to be regional (Treydte et al., 2007), overriding individual signals such as the species-specific physiology, the micro-site conditions and even the local 25 climate peculiarities.

The proxy record $\left(\delta^{13} \mathrm{C}\right)$ from Cazorla Range displays a regional correlation with a coherent decrease of the spatial significance (Fig. 3b). Calibration/verification was performed between the stable carbon isotope $\left(\delta^{13} \mathrm{C}\right)$ and instrumental June-to-September 4154
$7,4149-4171,2011$

\section{Evidence for a North Atlantic Oscillation outside its observed range}

C. Martín-Puertas et al.

\section{Title Page}

Abstract Introduction

Conclusions

Tables References Figures

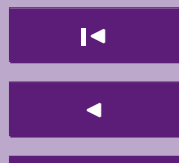

$\rightarrow 1$

Back

$\bullet$

Close

Full Screen / Esc

Printer-friendly Version

Interactive Discussion

\section{$\mathbf{I}$

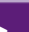 \\ sc

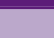

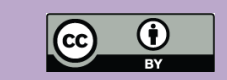


precipitation for the period 1901-2006 using the split-period procedure (Snee, 1977). Pearson's correlation coefficient ( $r$ ) and reduction of error (RE) (Cook et al., 1994) were calculated to test the validity of the model derived from the regression. Results show strong and temporally stable relationships between the tree-ring records and tar-

5 get climate variables (Table 1) and a good agreement on different frequency domains (Fig. 3c). Therefore, the validated models were used to reconstruct June-to-September precipitation (P0609) based on $\delta^{13} \mathrm{C}$. Uncertainties related to the precipitation reconstruction where calculated taking into consideration two sources: the calibration uncertainty and the residual uncertainty.

${ }_{10}$ In the context of the Mediterranean climate, the $\delta^{13} \mathrm{C}$ precipitation-sensitive proxy reflects the summer soil water balance since this is the limiting season for tree growth; however, ultimately, summer soil water balance depends also on the water recharge during the wetter seasons (Fig. 1d). Thus, summer precipitation is well correlated with the total annual precipitation anomalies $(r=0.58)$ suggesting that both follow the same 15 inter-annual variability. That means wet (dry) years are also characterized by wet (dry) summers (Fig. 3d).

\section{Results}

Precipitation reconstruction at the Cazorla site during the last $800 \mathrm{yr}$ shows that the highest precipitation occurred before and after the LIA, at AD 1250 and during the 20th 20 century (Fig. 4a). A decreasing trend is observed from AD 1200 up to 1360 followed by sustained lower mean values until $A D$ 1600. The $100 \mathrm{yr}$ interval from AD 1650 to 1750 is characterized by the lowest rainfall amounts and by a very low inter-annual variability. At the end of the 19th century, rainfall increases gradually until present day. The most significant minima occurred from AD 1650 to 1750, corresponding to the MM 25
7, 4149-4171, 2011

Evidence for a North Atlantic Oscillation outside its observed range

\section{Martín-Puertas et al.}

\section{Title Page}

Abstract

Conclusions

Tables

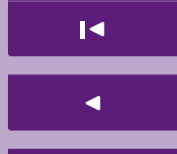

Back
Introduction

References

Figures

$\Delta$

Close

\section{Full Screen / Esc}

Printer-friendly Version

Interactive Discussion 


\section{Discussion}

\subsection{Regional pattern of hydrological variability in South-Western Europe}

The transition from the Medieval Climate Anomaly (MCA) to the LIA is evidenced in the Iberian Peninsula from AD 1200 to 1350 (Moreno et al., 2011). This transition was 5 characterized by a general cooling and an increase in the humidity that distinguished a warmer and arid MCA from a cooler and moister LIA on multi-centennial timescale (Moreno et al., 2011; Morellón et al., 2011). At the Cazorla site, more humid conditions are recorded at ca. AD 1250 (Fig. 4a), which likely correspond to that humidity increase. However, after this date averaged precipitation gradually decreases indicating relatively drier conditions at Cazorla that they were during the MCA-LIA transition (Moreno et al., 2011).

During the LIA (AD 1350-1850), decadal precipitation variability suggests solarclimate relationship, which describes solar minimum (maximum) coinciding with decrease (increase) in precipitation (Fig. 4). The MM was the driest period of the LIA over 15 the Cazorla region. These $100 \mathrm{yr}$ of persistent lower precipitation are in accordance with the increase in the number of rogations ceremonies as reflecting annual droughts across the Iberian Peninsula (Domínguez-Castro et al., 2010 and references therein) (Fig. 5a,b). The whole Cazorla reconstruction is corroborated by other low-resolution (multi-centennial) hydrological proxies in Spain (Fig. 5). For instance, flood episodes recorded in Taravilla Lake sediments $\left(40^{\circ} \mathrm{N}\right)$ (Moreno et al., 2008) and Guadalentin River $\left(38^{\circ} \mathrm{N}\right)$ (Benito et al., 2010) show a reduced activity from ca AD 1550 to present day (Fig. $5 \mathrm{c}, \mathrm{d})$ ) decreased runoff from the Zoñar Lake $\left(37^{\circ} \mathrm{N}\right)$ (Martin-Puertas et al., 2011) (Fig. 5e) and drier conditions in Southern and Central Euope for nearly the entire LIA (Nicault et al., 2008). Some discrepancies have been found in the Pyrenees (North(Morellón et al., 2011). In this region, the effect of the macro-relief (600-3000 m a.s.l) and its location perpendicular to several predominant air masses circulation cause a

Evidence for a North Atlantic Oscillation outside its observed range

C. Martín-Puertas et al.

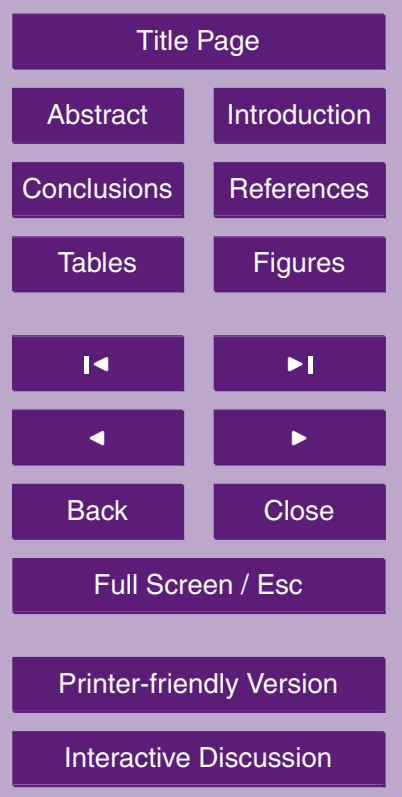

Interactive Discussion 
high climatic heterogeneity, which might lead to a more local signal (Lopez-Moreno et al., 2008).

Comparison of the hydrological variability over South-Western Europe (Cazorla, $37^{\circ} \mathrm{N}$ ) and North-Western Africa (Morocco, 34-32 $\mathrm{N}$ ) (Esper et al., 2007; Touchan 5 et al., 2011) shows an opposite trend during the LIA. In Morocco, wetter conditions prevailed from $A D 1450$ to 1980 preceded by drier conditions back to $A D$ 1450, including the end of MCA (Esper et al., 2007). The higher precipitation occurred before in Cazorla (AD 1250) than in Morocco suggesting the MCA-LIA transition was earlier in the Iberian Peninsula. From AD 1200, rainfall starts decreasing in lberia while it increases 10 gradually in Morocco. At the onset of the LIA ( AD 1350), precipitation is increasing in Morocco but low in the South of Spain until the mid 19th century (Fig. 5f,g).

\subsection{Driving mechanisms and climate forcing}

Presently, the variability of the atmospheric circulation over the Atlantic-European region determines the spatial distribution of the precipitation and describes a similar pat15 tern in South-Western Europe and North-Western Africa. The apparent hydrological discrepancies between these two areas during the LIA suggests a shift in that rainfall distribution. The most important regional circulation modes affecting climate over Western Europe (including the British Isles, Ireland, the Iberian Peninsula and Morocco) are the AO/NAO (34.7\%) and the Eastern Atlantic pattern (EA) (17.7\%) (Zveryaev et al., 20 2008). The NAO and the EA are structurally similar: a seesaw of atmospheric pressure between sub-polar low and subtropical high; but the EA centres of actions are located southward and it is often interpreted as an equatorward shifted AO/NAO pattern (Barnston and Livezey, 1987). In any case, both modes modulate the magnitude and the latitudinal trajectory of the mid-latitude westerlies (storm-tracks) in the North Atlantic 25 realm through AO/NAO-like pattern (Hurrell, 1995; Wibig, 1999). The EA is further connected to the Western Russian pattern (WR) composing the EA/WR teleconnection during wintertime (Krichak et al., 2002), also called the Eastern Europe pattern (EE) (Wibig, 1999) or the EU2 (Barnston and Livezey, 1987). The EA/WR consists of four
7, 4149-4171, 2011

\section{Evidence for a North Atlantic Oscillation outside its observed range}

C. Martín-Puertas et al.

Title Page

Abstract Introduction

Conclusions

Tables

References

Figures

14

$\rightarrow 1$

4

Back

Close

Printer-friendly Version

Interactive Discussion

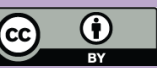


main anomaly centres located over British Isles and Central North Atlantic (EA), North Black-Caspian Sea and Northern China constituting meridional flows. Physical mechanisms responsible for the EA-WR trend are not fully understood, but there is a correlation between negative phases of both the EA/WR and the NAO (Feldstein, 2000). A 5 negative EA/WR brings moist air to the North-Western and South-Eastern European shores but it does not affect the study region significantly (Wibig, 1999). Possible variations in time of the latitudinal distribution of precipitation in the North Atlantic-European region, such as the one observed in the Iberian Peninsula with respect to its southern neighbor during the LIA, could be mainly triggered by zonal (AO/NAO-like) rather than 10 meridional atmospheric circulation.

The MCA-LIA transition has been suggested to experience a shift from positive to negative index of the AO/NAO-like (Trouet et al., 2009). This implies a southward migration of the North Atlantic/West European storm tracks leading to a gradual precipitation increase in Iberia. This gradual displacement to the south can explain the 15 earlier MCA-LIA transition in the Iberian Peninsula (prior AD 1250) in comparison with Morocco (AD 1250-1450) (Esper et al., 2007) (Fig. 3f,g). Accepting predominance of a negative NAO mode during the LIA, a possible explanation for less precipitation in the study site since AD 1250 might be the southernmost position of the rain belt southern of the Cazorla latitude -, which points to a NAO excursion outside the observational range. The atmospheric circulation during the 2009/2010 winter - the most negative NAO recorded in the instrumental series -, situated the rain band between $38^{\circ} \mathrm{N}$ and $32^{\circ} \mathrm{N}$ (Fig. 1a). Since this region appears dry in our reconstruction during the LIA we assume that the mean position of the rain belt was located even $2^{\circ}$ further south $(300 \mathrm{~km})$. A comparable observation has been made for the Intertropical Convergence Zone (ITCZ) in the Atlantic ( $5^{\circ}$ south) (Haug et al., 2001$)$ and the Pacific oceans ( $\sim 500 \mathrm{~km}$ south of the modern position) (Sachs et al., 2009) during the same time interval; and for the polar front in the North Atlantic regions implying a reduction of the Meridional Overturning Circulation (Sicre et al., 2008). This coincidence suggests coherent changes of atmospheric circulation on a hemispheric scale (tropical, mid and
$7,4149-4171,2011$

\section{Evidence for a North Atlantic Oscillation outside its observed range}

C. Martín-Puertas et al.

\section{Title Page}

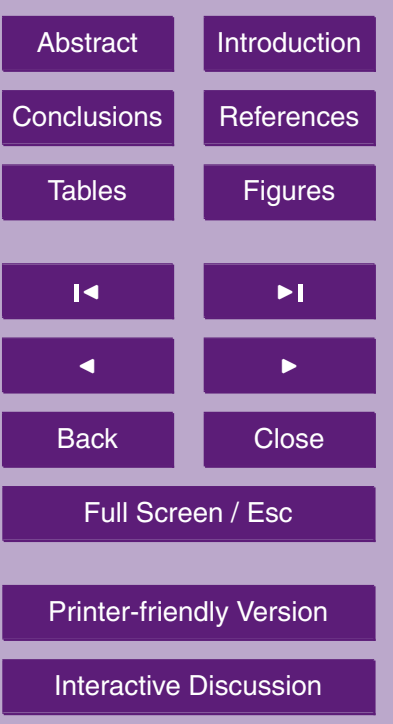


polar-circulation), likely induced by a common forcing. The migration of the ITCZ has been related to a reduction in the solar irradiance at AD 1400 until 1850 (Haug et al., 2001; Sachs et al., 2009). The Cazorla data further suggests a solar-climate link at inter-decadal timescale since the two driest stages described from the Cazorla archive 5 during the LIA (Figs. 2 and 3) and interpreted as extreme negative NAO coincide with the Maunder and the Dalton minima.

A stronger negative excursion of the NAO during the LIA beyond the 20th century range (e.g winter 2009/10) is further supported by following scenarios: (1) solar irradiance during the LIA might have been lower than observed today (Shapiro et al., 2011);

10 (2) high volcanic activity coinciding with the solar minima during AD 1400-1850 might have contributed to a further southward displacement of North Atlantic mid-latitude storm tracks (Haigh et al., 2005); (3) anthropogenic $\mathrm{CO}_{2}$ forcing might have caused a northward displacement of the range of migration of the storm tracks associated to mid-latitude westerlies during the instrumental period of the NAO index (Chen et al., 15 2008; Bender et al., 2011).

\section{Conclusions}

The Pinus nigra subsp. salzmannii (Dunal) forest from the Natural Park of Sierra de Cazorla, Segura y las Villas $\left(37^{\circ} \mathrm{N}\right)$ provides the first tree ring-proxy precipitation reconstruction of the Little Ice Age (LIA) for Southern Spain that reveals high- to lowfrequency variability. The results show a decrease in the mean values of precipitation during the cooling episodes of the LIA and "drought stages" coinciding with the Maunder and Dalton solar minima. Moreover, this hydrological pattern over Southwestern Europe is opposite to that observed in Northwestern Africa (Morocco) suggesting a different spatial distribution of the precipitation that observed in the instrumental record. This unusual situation might be explained by a solar-induced extreme NAO excursion and consequently a displacement of the storm tracks of $2^{\circ}$ further south of the instrumental range. We suggest that the relationship between atmospheric circulation patterns and climate-proxy might not be stable in time; and the consideration

\section{9}

4159
$7,4149-4171,2011$

\section{Evidence for a North Atlantic Oscillation outside its observed range}

C. Martín-Puertas et al.

Title Page

Abstract Introduction

Conclusions

Tables References Figures

14

$>\mathbf{I}$

4

Back

Close

Full Screen / Esc

Printer-friendly Version

Interactive Discussion 
of changes in the geographical distribution of precipitation in climate models reconstructing the NAO could influence on simulations.

Acknowledgements. This research was funded by EU projects ISONET (Contract EV K2-200100237) and MILLENNIUM (017008-2). C. Martin-Puertas thanks funding from the Alexander 5

\section{References}

Andreu, L., Planells, O., Gutiérrez, E., Helle, G., and Schleser, G. H.: Climatic significance of tree-ring width and $\delta^{13} \mathrm{C}$ in a Spanish pine forest network, Tellus B, 60, 771-781, 2008.

Andreu-Hayles, L., Planells, O., Gutiérrez, E., Muntán, E., Helle, G., Anchukaitis, K. J., and Schleser, G. H.: Long tree-ring chronologies reveal 20th century increases in water-use efficiency but no enhancement of tree growth at five Iberian pine forests, Glob. Change Biol., 17, 2095-2112, 2011.

Barnston, A. G. and Livezey, R. E.: Classification, seasonality and persistence of low frequency atmospheric circulation patterns, Mon. Weather Rev., 115, 1083-1126, 1987.

15 Barriendos, M.: Climatic variations in the Iberian Peninsula during the late Maunder Minimum (AD 1975-1715): an analysis of data from rogation ceremonies, Holocene, 7, 105-111, 1997.

Bender, F. A. M., Ramanathan, V., and Tselioudis, G.: Changes in extratropical storm track cloudiness 1983-2008: observational support for a poleward shift, Clim. Dynam., in press, doi:10.1007/s00382-011-1065-6, 2011.

Benito, G., Rico, M., Sánchez-Moya, Y., Sopeña, A., Thorndycraft, V. R., and Barriendos, M.: The impact of late Holocene climatic variability and land use change on the flood hydrology of the Guadalentin River, Southeast Spain, Global Planet. Change, 70, 53-63, 2010.

Chen, G., Lu, J., and Frierson, D. M. W.: Response of the zonal mean atmospheric circulation

25 to El Niño versus global warming, J. Climate, 21, 5835-5851, 2008.

Creus Novau, J.: A propósito de los árboles más viejos de la España Peninsular: Los Pinus nigra Arnold subsp. Salzmanii (Dunal) Franco de Puertollano-Cabañas, Sierra de Cazorla, Jaén, Rev. Montes, 54, 68-76, 1998.

Cook, E. R., Briffa, K. R., and Jones, P. D.: Spatial regression methods in dendroclimatology: a

$7,4149-4171,2011$

\section{Evidence for a North Atlantic Oscillation outside its observed range}

\section{Martín-Puertas et al.}

\section{Title Page}

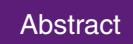

Introduction

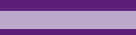

References

Conclusions

References

Tables

Figures

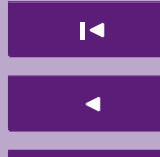

$>1$

Back

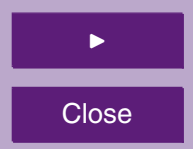

Full Screen / Esc

Printer-friendly Version

Interactive Discussion 
Domínguez-Castro, F., García-Herrera, R., Ribera, P., and Barriendos, M.: A shift in the spatial pattern of Iberian droughts during the 17th century, Clim. Past, 6, 553-563, doi:10.5194/cp6-553-2010, 2010.

Domínguez-Castro, F., Ribera, P., García-Herrera, R., Vaquero, J. M., Barriendos, M., Cuadrat, 5 J. M., and Moreno, J. M.: Assessing extreme droughts in the Iberian Peninsula during 17501850 from rogation ceremonies, Clim. Past Discuss., 7, 4037-4072, doi:10.5194/cpd7-4037-2011, 2011.

Dorado Liñán, I.: Millennial tree-ring proxy based climate reconstructions at the Iberian Peninsula: challenges and strengths, PhD Thesis, Universidad de Barcelona, Barcelona, 246 pp., 102011.

Dorado Liñán, I., Gutiérrez, E., Helle, G., Heinrich, I., Andreu-Hayles, L., Planells, O., Leuenberger, M., Bürger, C., and Schleser, G. H.: Pooled versus separate measurements of treering stable isotopes, Sci. Total Environ., 409, 2244-2251, 2011.

Esper, J., Frank., D., Büntgen, U., Verstege, A., Luterbacher, J., and Xoplaki, E.: 15 Long-term drought severity variations in Morocco, Geophys. Res. Lett., 34, L17702, doi:10.1029/2007GL030844, 2007.

Feldtein, S. B.: The timescale, power, spectra and climate noise properties of teleconnection patterns, J. Climate, 13, 4430-4440, 2000.

Gagen, M., McCarroll, D., and Edouard, J. L.: Combining tree ring width, density and stable carbon isotope series to enhance the climate signal in tree rings: an example from the French Alps, Climatic Change, 78, 363-379, 2006.

Gagen, M., McCarroll, D., Loader, N. J., Robertson, I., Jalkanen, R., and Anchukaitis, K. J.: Exorcising the "segment length curse": summer temperature reconstruction since AD 1640 using non-detrended stable carbon isotope ratios from pine trees in Northern Finland, Holocene, 17, 435-446, 2007.

Haigh, J. D., Blackburn, M., and Day, R.: The response of tropospheric circulation to perturbations in lower-stratospheric temperature, J. Climate, 18, 3672-3684, 2005.

Haug, G. H., Hughen, K. A., Sigman, D. M., Peterson, L. C., and Röhl, U.: Southward migration of the Intertropical Convergence Zone through the Holocene, Science, 293, 1304-1308, 302001 .

Heywood, V. H.: The flora of the Sierra de Cazorla, SE Spain I. Fedde, Repertorium, 64, 28-73, 1961.

Holmes, R. L.: Computer-assisted quality control in tree-ring dating and measurement, Tree-
$7,4149-4171,2011$

\section{Evidence for a North Atlantic Oscillation outside its observed range}

C. Martín-Puertas et al.

\section{Title Page}

\begin{tabular}{c|c}
\hline Abstract & Introduction \\
\hline Conclusions & References \\
\hline Tables & Figures \\
\hline I4 & $>$ I \\
\hline 4 & $\bullet$ \\
\hline Back & Close \\
\hline Full Screen / Esc \\
\hline Printer-friendly Version
\end{tabular}

Interactive Discussion 
Ring Bull., 43, 69-78, 1983.

Hurrell, J. W.: Decadaal trends in the North Atlantic oscillation: regional temperatures and oscillation, Science, 269, 676-679, 1995.

Ineson , S., Scaife, A. A., Knight, J. R., Manners, J. C., Dunstone, N. J., Gray, L. J., and 5 Haigh, J. D.: Solar forcing of winter climate variability in the Northern Hemisphere, Nat. Geosci., 4, 753-757, doi:10.1038/NGEO1282, 2011.

Kodera, K.: Solar cycle modulation of the North Atlantic oscillation: implication in the spatial structure of the NAO, Geophys. Res. Lett., 29, 1218, doi:10.1029/2001GL014557, 2002.

Krichak, S. O., Kishcha, P., and Alpert, P.: Decadal trends of main Eurasian oscillations and the Mediterranean precipitation, Theor. Appl. Climatol., 72, 209-220, 2002.

Langematz, U., Claussnitzer, A., Matthes, K., and Kunze, M.: The climate during the Maunder Minimum: a simulation with the Freie Universität Berlin Climate Middle Atmosphere Model (FUB-CMAM), J. Atmos. Sol-Terr. Phy., 67, 55-69, 2005.

Lopez-Moreno, J. I., Goyette, S., and Beniston, M.: Climate change prediction over complex 15 areas: spatial variability of uncertainties and predictions over the Pyrenees from a set of regional climate models, Int. J. Climatol., 28, 1535-1550, 2008.

Martín-Puertas, C., Valero-Garcés, B. L., Mata, M. P., Moreno, A., Giralt, S., Martínez-Ruiz, F., and Jiménez-Espejo, F.: Geochemical processes in a Mediterranean Lake: a high-resolution study of the last 4000 years in Zoñar Lake, Southern Spain, J. Paleolimnol., 46, 405-421, doi:10.1007/s10933-009-9373-0, 2011.

Matthes, K.: Solar cycle and climate predictions, Nat. Geosci., 4, 735-736, 2011.

Matthes, K., Kudora, Y., Kodera, K., and Langematz, U.: Tranfer of the solar signal from the stratosphere to the troposphere: northern winter, J. Geophys. Res., 111, D06108, doi:10.1029/2005JD006283, 2006.

Mitchell, T. D. and Jones, P. D.: An improved method of constructing a database of monthly climate observations and associated high-resolution grids, Int. J. Climatol., 25, 693-712 , 2005.

Moreno, A., Valero-Garcés, B. L., González-Sampériz, P., and Rico, M.: Flood response to rainfall variability during the last 2000 years inferred from the Taravilla Lake record (Central Iberian Range, Spain), J. Paleolimnol., 40, 943-961, 2008.

Moreno, A., Morellón, M., Martín-Puertas, C., Frigola, J., Canals, M,, Cacho, I., Corella, J. P., Pérez, A., Belmonte, A., Vegas-Vilarrúbia, T., González-Sampériz, P., Valero-Garcés, B. L.: Was there a common hydrological pattern in the Iberian Peninsula region during the Medieval
$7,4149-4171,2011$

\section{Evidence for a North Atlantic Oscillation outside its observed range}

C. Martín-Puertas et al.

\section{Title Page}

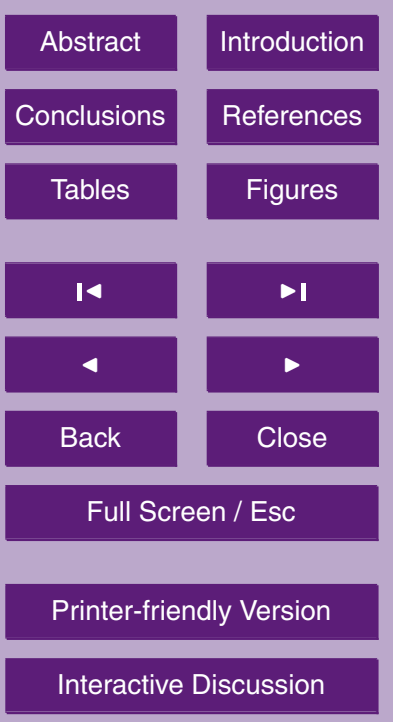

\section{2}


Climate Anomaly?, PAGES News, 19, 16-18, 2011.

Morellón, M., Pérez-Sanz, A., Corella, J. P., Büntgen, U., Catalán, J., González-Sampériz, P., González-Trueba, J. J., López-Sáez, J. A., Moreno, A., Pla, S., Saz-Sánchez, M. Á., Scussolini, P., Serrano, E., Steinhilber, F., Stefanova, V., Vegas-Vilarrúbia, T., and Valero5 Garcés, B.: A multi-proxy perspective on millennium-long climate variability in the Southern Pyrenees, Clim. Past Discuss., 7, 3049-3089, doi:10.5194/cpd-7-3049-2011, 2011.

Nicault, A., Alleaume, S., Brewer, S., Carrer, M., Nola, P., Gutiérrez, E., Edouard. J. L., Urbinati, C., and Guiot, J.: Mediterranean drought fluctuation during the last 500 years based on tree-ring data, Clim. Dynam., 31, 227-245, 2008.

10 Pfister., C.: Climate since AD 1500, edited by: Bradley, R. S., Jones, P. D., Routledge, London, 118-142, 1995.

Rodrigo, F. S. and Barriendos, M.: Reconstruction of seasonal and annual rainfall variability in the Iberian península (16th-20th centuries) from documentary data, Global Planet. Change, 63, 243-527, 2008.

Seager, R., Kushmir, Y., Nakamura, J., Ting, M., and Naik, N.: Northern Hemisphere winter snow anomalies: ENSO, NAO and the winter of 2009/10, Geophys. Res. Lett., 37, L14703, doi:10.1029/2010GL043830, 2010.

Sachs, J. P., Sachse, D., Smittenberg, R. H., Zhang, Z., Battisti, D., and Golubic, S.: Southward movement of the Pacific intertropical convergence zone AD 1400-1850, Nat. Geosci., 2, 519-524, 2009.

Shapiro, A. I., Schmutz, W., Rozanov, E., Schoell, M., Haberreiter, M., Shapiro, A. V., and Nyeki, S.: A new approach to long-term reconstruction of the solar irradiance leads to large historical solar forcing, Astron. Astrophys., 529, A67, doi:10.1051/0004-6361/201016173, 2011.

Shindell, D. T., Schmidt, G. A., Mann, M. E., Rind, D., and Waple, A.: Solar forcing of regional climate change during the Maunder Minimum, Science, 294, 2149-2152, 2001.

Sicre, M. A., Jacob, J., Ezat, U., Rousse, S., Kissel, C., Yiou, P., Eriksson, J., Knudsen K. L., Jansen, E., and Turon, J.-L.: Decadal variability of sea surface temperatures off North Iceland over the last 2000 years, Earth Planet. Sci. Lett., 268, 137-142, 2008.

30 Snee, R. D.: Validation of regression models: models and examples, Technometrics, 19, 415428, 1977.

Touchan, R., Anchukaitis, K. J., Meko, D. M., Sabir, M., Attalah, S., and Aloui, A.: Spatiotemporal drought variability in Northwestern Africa over the last nine centuries, Clim. Dynam., 37,
$7,4149-4171,2011$

\section{Evidence for a North Atlantic Oscillation outside its observed range}

C. Martín-Puertas et al.

\section{Title Page}

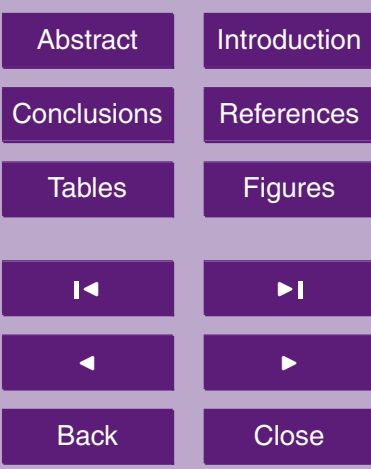

Full Screen / Esc

Printer-friendly Version

Interactive Discussion 
237-252, 2011.

Treydte, K., Schleser, G. H., Schweingruber, F. H., and Winiger, M.: The climatic significance of $\delta^{13} \mathrm{C}$ in subalpine spruces (Lötschental, SwissAlps), Tellus, 53, 593-611, 2001.

Treydte, K. S., Frank, D., Andreu, L., Bednarz, Z., Berninger, F., Boettger, T., 5 D’Allessandro, C. D., Esper, J., Etien, N., Filot, M., Grabner, M., Guillemin, M. T., Gutierrez, E., Haupt, M., Helle, G., Hilasvuori, E., Jungner, H., Kalela-Brundin, M., Krapiec, M., Leuenberger. M., Loader, N. J., Masson-Delmotte, V., Pazdur, A., Pawelczyk, S., Pierre, M., Planells, O., Pukiene, R., Reynolds, C., Rinne, K., Saracino, A., Saurer, M., Sonninen, E., Stievenard, M., Switsur, V. R., Szczepanek, M., Szychowska-Krapiec, E., Todaro, L., Waterhouse, J. S., Weigl, M., and Schleser, G. H.: Signal strength and climate calibration of a European tree-ring isotope network, Geophys. Res. Lett., 34, L24302, doi:10.1029/2007GL031106, 2007.

Trouet, V., Esper, J., Graham, N. E., Baker, A., Scourse, J., and Frank, D.: Persistent positive North Atlantic oscillation mode dominated the medieval climate anomaly, Science, 324, 7880, 2009.

Vicente-Serrano, S. M. and Cuadrat, J. M.: North Atlantic oscillation control of drought in NorthEast Spain: evaluation since 1600 AD, Climatic Change, 85, 357-379, 2007.

Vicente-Serrano, S. M., Trigo, R. M., Loper-Moreno, J. I., Liberato, M. L. R., Lorenzo-Lacruz, J., Begueria, S., Moran-Tejada, E., and Kenawy, A. E.: Extreme winter precipitation in the Iberian Peninsula in 2010: anomalies, driving mechanisms and future projections, Climate Res., 46, 51-65, 2011.

Voltas, J., Chambel, M. R., Prada, M. A., and Ferrio, J. P.: Climate-related variability in carbon and oxygen stable isotopes among populations of Aleppo pine grown in common-garden tests, Trees, 22, 759-769, 2008.

Wanner, H., Beer, J., Bütikofer, J., Crowley, T. J., Cubasch, U., Flückiger, J., Goosse, H., Grosjean, M., Joos, F., Kaplan, J. O., Küttel, M., Müller, S. A., Prentice, I. C., Solomina, O., Stocker, T. F., Tarasov, P., Wagner, M., and Widmann, M.: Mid- to late holocene climate change: an overview, Quaternary Sci. Rev., 27, 1791-1828 , 2008.

Wibig, J.: Precipitation in Europe in relation to circulation patterns at the $500 \mathrm{hPa}$ level, Int. J. $30 \quad$ Climatol., 19, 253-269, 1999.

Zveryaev, I., Wibig, J., and Allan, R.: Contrasting interannual variability of atmospheric moisture over Europe during cold and warm seasons, Tellus A, 60, 32-41, 2008
$7,4149-4171,2011$

\section{Evidence for a North Atlantic Oscillation outside its observed range}

C. Martín-Puertas et al.

Title Page

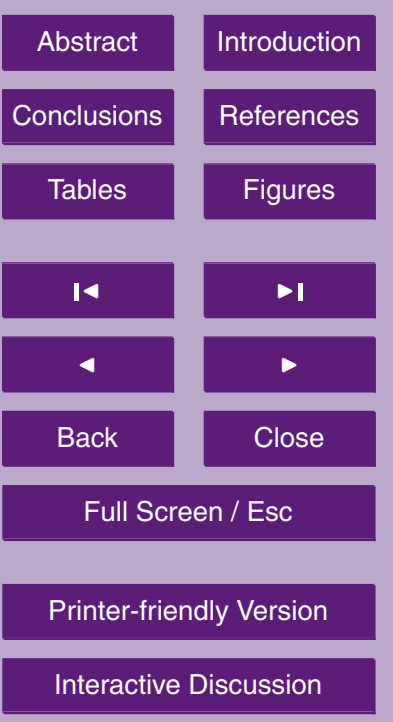




\section{Evidence for a North Atlantic Oscillation outside its observed range}

Table 1. Calibration-verification statistics for the precipitation reconstruction based on stable carbon isotope $\left(\delta^{13} \mathrm{C}\right) . r^{2}$ is the coefficient of determination; $r_{\text {obs-pred }}$ is the correlation between the real and the predicted values and RE is the reduction of error.

\begin{tabular}{llcccccc}
\hline $\begin{array}{l}\text { Tree-ring } \\
\text { proxy }\end{array}$ & $\begin{array}{l}\text { Seasonal } \\
\text { variable }\end{array}$ & $\begin{array}{c}\text { Calibration 1 } \\
(1901-1953)\end{array}$ & \multicolumn{2}{c}{$\begin{array}{c}\text { Verification 1 } \\
(1954-2006)\end{array}$} & $\begin{array}{c}\text { Calibration 2 } \\
(1954-2006)\end{array}$ & \multicolumn{2}{c}{$\begin{array}{c}\text { Verification 1 } \\
(1901-1953)\end{array}$} \\
\hline$\delta^{13} \mathrm{C}$ & $\begin{array}{l}\text { Jun-Sep } \\
\text { precipitation }\end{array}$ & $20.9 \%$ & 0.46 & 0.19 & $17.1 \%$ & 0.41 & 0.15 \\
\hline
\end{tabular}

Title Page

Abstract

Conclusions

Tables
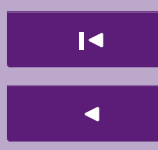

Back

Full Screen / Esc

Printer-friendly Version

Interactive Discussion 


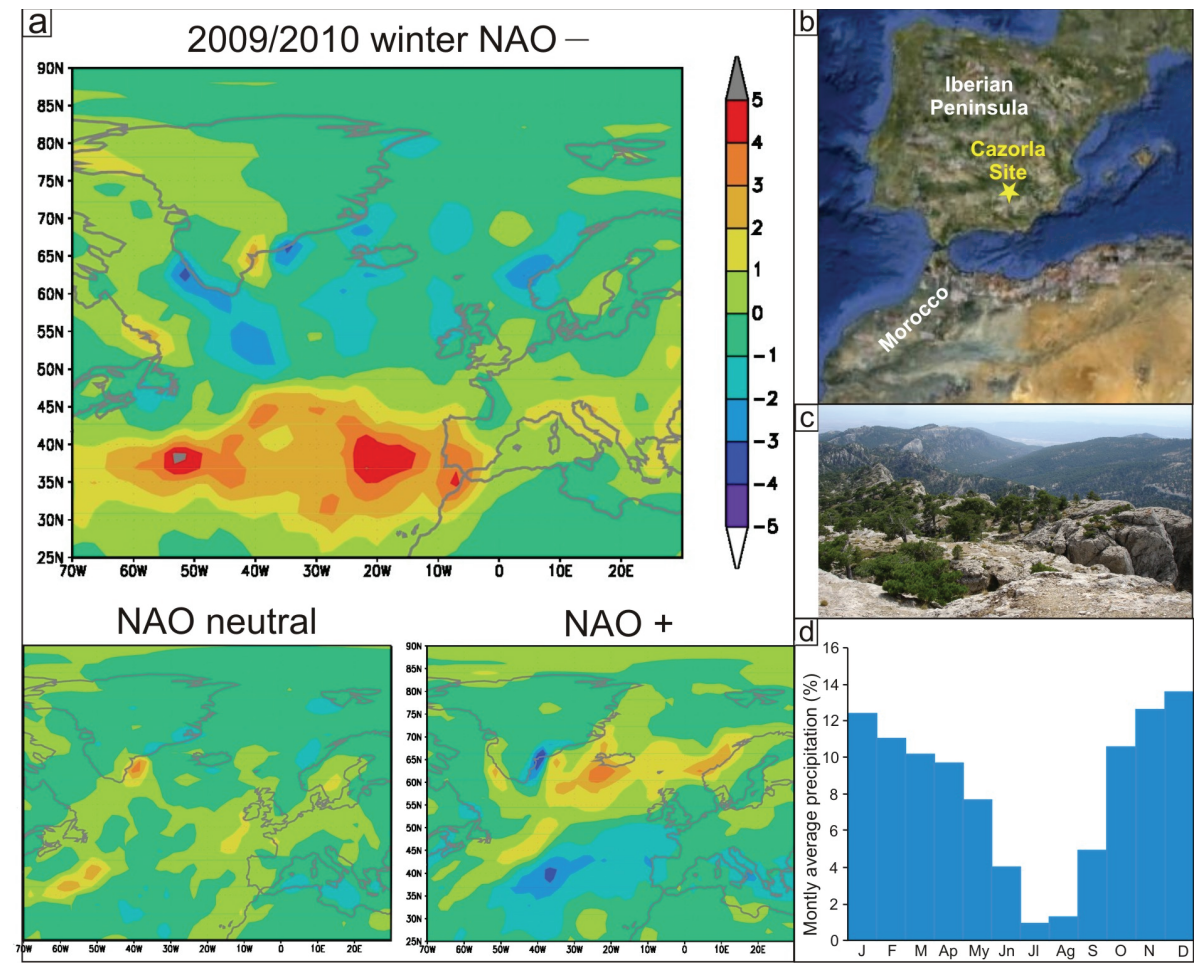

Fig. 1. (a) Winter precipitation deviations $\left(\mathrm{mm} \mathrm{month}^{-1}\right)$ from their long-term mean in the North Atlantic European region observed in three winters. Top, in 2009/2010 with the most negative observed value of the NAO index since 1821; bottom left, in 1987/1988 with a NAO index close to zero; bottom right, in the winter 1988/1989 with one of the highest observed NAO index. Precipitation data are from the NCEP/NCAR meteorological reanalysis. (b) Cazorla site. (c) Pinus nigra subsp. salzmannii (Dunal) forest in Cazorla. (d) Monthly average precipitation distribution in Andalusia expressed as percentages. Resource: Andalusia Government.
Evidence for a North Atlantic Oscillation outside its observed range

C. Martín-Puertas et al.

\section{Title Page}

\section{Abstract}

Conclusions

Tables

\section{References}

Figures

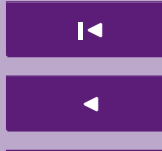

Back

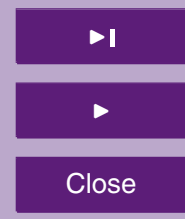

Full Screen / Esc

Printer-friendly Version

Interactive Discussion 


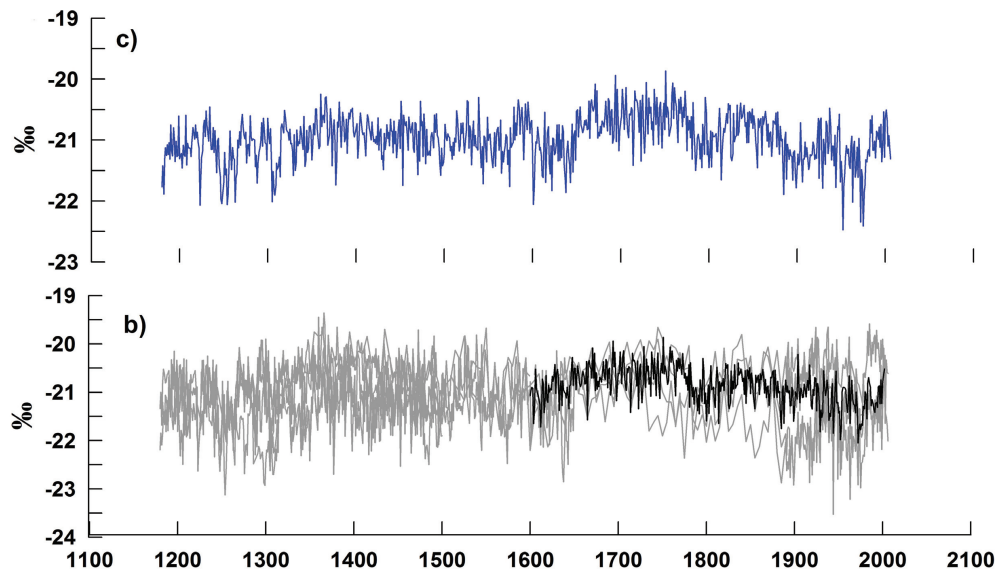

\section{$7,4149-4171,2011$}

Evidence for a North Atlantic Oscillation outside its observed range

C. Martín-Puertas et al.

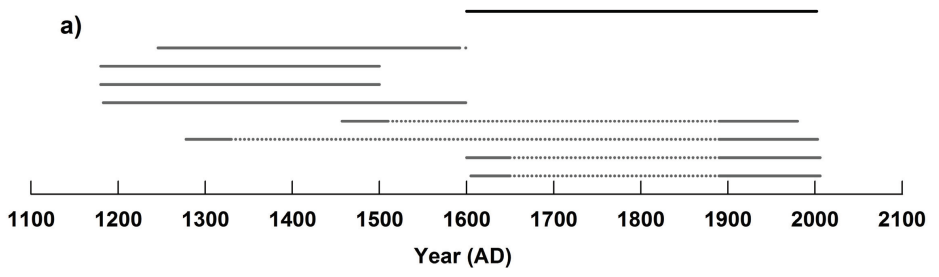

Fig. 2. Stable carbon isotope chronology from Cazorla Site $\left(\delta^{13} \mathrm{C}\right)$. (a) Time-span of the individual trees (grey lines) and the pool chronology (black line). Discontinuous line indicates measurements every five year, while continuous line indicates annual resolution. (b) Plot of the individual series (grey) and the pool chronology (black). (c) Final chronology with annual resolution resulting from the combination of the individual series and the pool chronology.

Title Page

Abstract

Conclusions

Tables

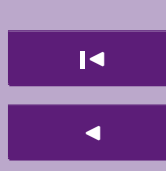

Back

Full Screen / Esc

Printer-friendly Version

Interactive Discussion 


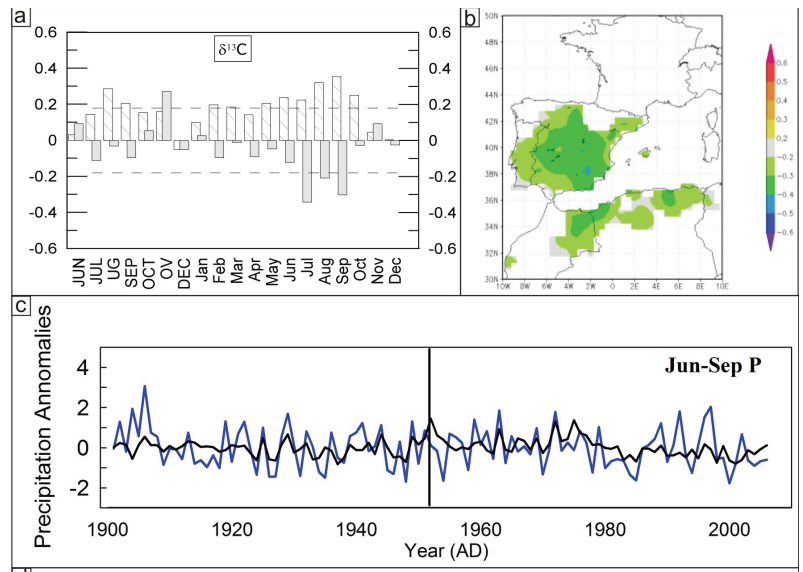

7, 4149-4171, 2011

Evidence for a North Atlantic Oscillation outside its observed range

C. Martín-Puertas et al.

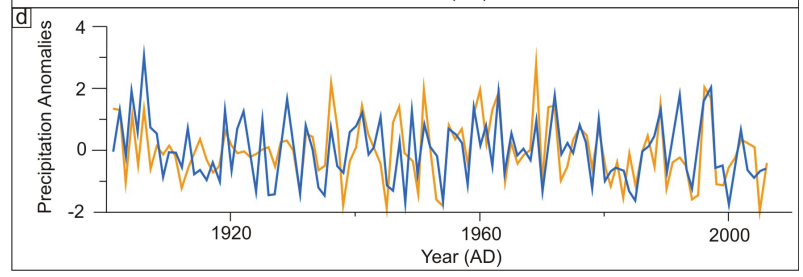

Title Page

Abstract

Conclusions

Tables

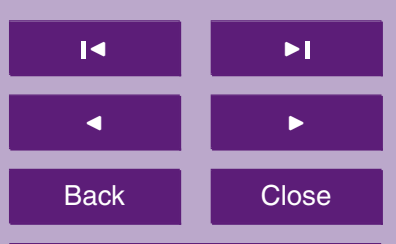

Full Screen / Esc

Printer-friendly Version

Interactive Discussion 


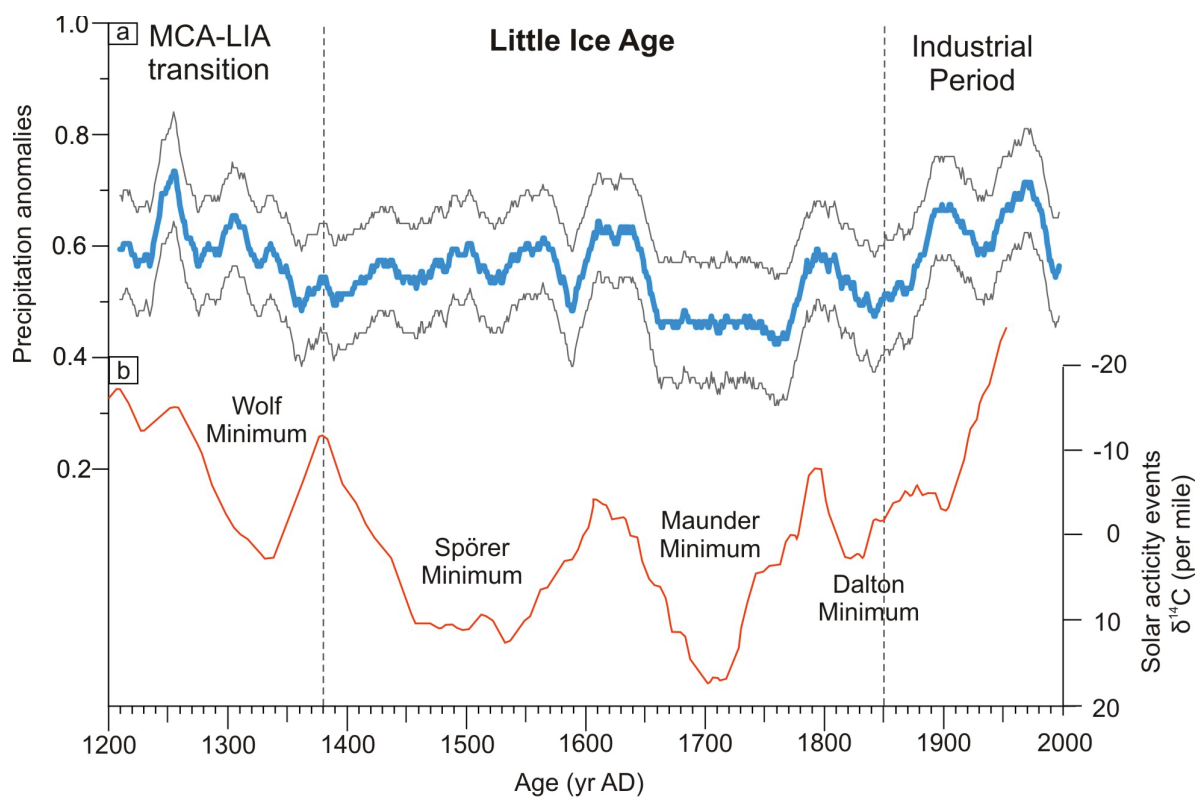

Fig. 4. (a) June to September precipitation anomalies reconstruction based on tree-rings from Cazorla site. Shaded area represents the uncertainty related to the calibration model used for reconstruction and the regression parameter. Smoothing with a 21-yr filter; (b) solar activity expressed as $\delta^{14} \mathrm{C}$ (per mile). Resource: http://www.radiocarbon.org/IntCal04\%20files/intcal04. $14 \mathrm{c}$.
Evidence for a North Atlantic Oscillation outside its observed range

C. Martín-Puertas et al.

Title Page
Abstract

Conclusions

Tables

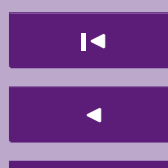

Back
Introduction

References

Figures

$>1$

D

Close
Full Screen / Esc

Printer-friendly Version

Interactive Discussion 

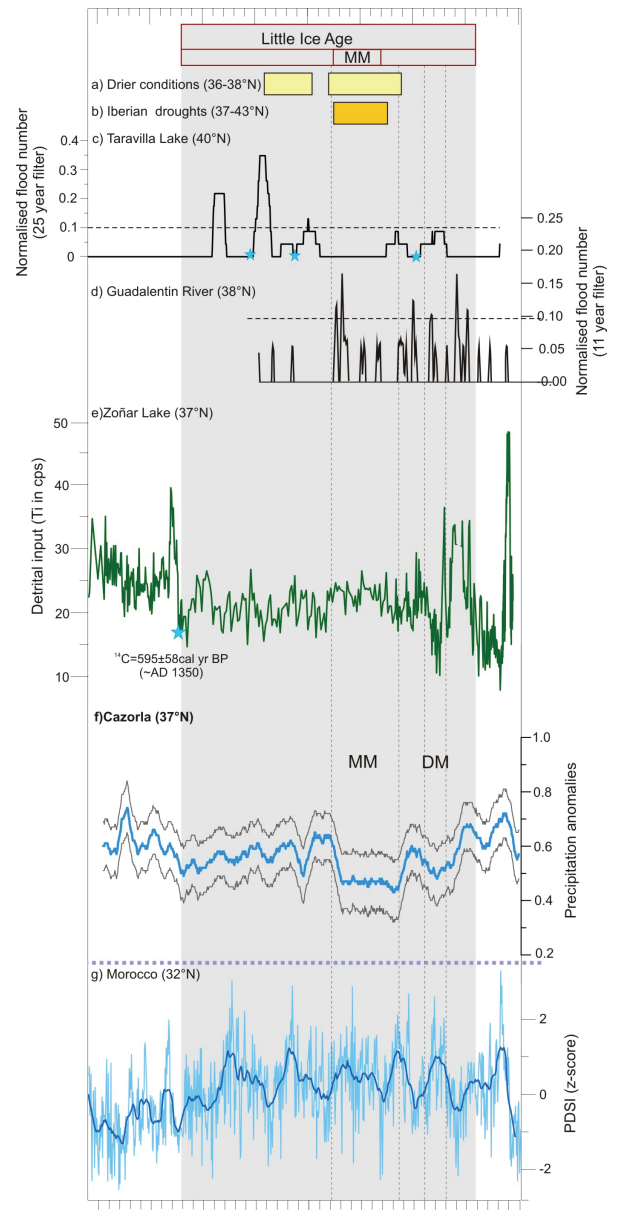

$\begin{array}{lllllllll}1200 & 1300 & 1400 & 1500 & 1600 & 1700 & 1800 & 1900 & 2000\end{array}$ Age (yr AD)

Fig. 5. Caption on next page.
7, 4149-4171, 2011

Evidence for a North Atlantic Oscillation outside its observed range

C. Martín-Puertas et al.

Title Page

Abstract Introduction

Conclusions

References

Tables

Figures
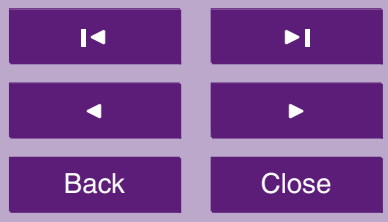

Full Screen / Esc

Printer-friendly Version

Interactive Discussion 


\section{Evidence for a North Atlantic Oscillation outside its observed range}

Fig. 5. Southern Europe and Northern Africa precipitation proxy records during the last $900 \mathrm{yr}$. (a, b) Periods of rogation ceremonies praying for rain (Barriendos, 1997; Domínguez-Castro et al., 2010); (c) paleflood reconstruction from Taravilla Lake (adapted from Moreno et al., 2008) and (d) paleoflood reconstruction from Guadalentin River (Benito et al., 2010). The horizontal dotted line marks the threshold above which flood are considered exceptionally; (e) detrital input into the Zoñar Lake as reflected by Ti intensities in counts per second (cps) as a indicator of precipitation in Southern Spain (adapted from Martin-Puertas et al., 2011); (f) tree ring-based precipitation reconstruction in the Cazorla region (this study) and (g) tree ring-based PDSI index for Morocco smoothed with a 20-yr filter and expressed as z-score (Esper et al., 2007). Blue stars show radiocarbon dates used for each depth/age model.

C. Martín-Puertas et al.

Title Page

Abstract

Conclusions

Tables

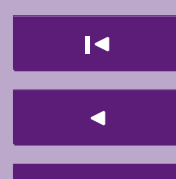

Back
Introduction

References

Figures

$\rightarrow$ I

Close

Full Screen / Esc

Printer-friendly Version

Interactive Discussion 